\title{
Clinical, laboratory and ultrasound profile of patients with thyroid cysts
}

\begin{abstract}
Introduction: Thyroid nodules are very frequent in the general population, affecting about $6 \%$ of adult women and $2 \%$ of men. An accurate ultra -sonographic evaluation shows that approximately two thirds of all women and one third of all men have small nodules in their glands. True simple thyroid cysts originating from benign epithelial cells are rare. Most cystic nodules are partially solid structures with cystic degeneration (mixed or complex nodules). The clinical-laboratory characteristics of solid or complex thyroid nodules are well known because of their possible association with malignancy, but the characteristics of simple cystic nodules have not been fully determined.
\end{abstract}

Material and methods: The study was conducted on 225 patients with thyroid nodules (18 men and 207 women) ranging in age from 18 to 87 years who were divided into 4 groups: GROUP 1 -patients with SIMPLE CYSTS, GROUP 2- patients with SIMPLE CYSTS associated with SOLID NODULES, GROUP 3- patients with PURE SOLID NODULES, and GROUP 4- patients with COMPLEX NODULES. TSH, free T4, free T3, Thyroglobulin, Anti-Thyroperoxidase Antibody, Anti-Thyroglobulin antibody and Anti-TSH Receptor Antibody (TRAB) were determined.

Results and discussion: SIMPLE CYSTS were not infrequent in the population studied. Single SIMPLE CYSTS occurred in a younger population compared to the remaining types of nodules. SINGLE SIMPLE CYSTS were less frequent than SIMPLE CYSTS associated with SOLID NODULES .SINGLE SIMPLE CYSTS, cysts associated with SOLID NODULES and COMPLEX CYSTS were found to be all benign in the present study.

Conclusion: COMPLEX CYSTS were the most frequent nodules and also the largest among these patients. Anti-TPO, Anti-Tgand Thyroglobulin levels were higher in patients with SIMPLE CYSTS associated with Clinical Hypothyroidism and Hashimoto Thyroiditis. The single case of thyroid carcinoma was detected here in a single Solid Nodule.

Keywords: goiter, solid thyroid nodule, complex thyroid nodule, thyroid cysts, thyroid ultra sonography
Special Issue - 2018

\author{
Maria Lucia D ArboAlves,' Manoel Henrique \\ Cintra Gabarra ${ }^{2}$ \\ 'Medical Course, Universityof Ribeirao Preto, Brazil \\ ${ }^{2}$ Engineering Course, Universityof Ribeirao Preto, Brazil
}

Correspondence: Maria Lucia D Arbo Alves, MedicalCourse, Universityof Ribeira Preto, Brazil, Email mldarbo@bol.com.br

Received: March 17, 2017 | Published: November 15, 2018
Abbreviations: TSH, thyrotropin hormone; FT4, tiroxina livre; FT3, triiodotironina livre; Tg, Tyroglobulin; Anti TPO, anticorpo antitireoidiano; AntiTg. anticorpo antitireoglobulina; TRAB, anticorpo estimulador do receptor de TSH

\section{Introduction}

The thyroid gland is the first endocrine gland arising in the human embryo, developing as a diverticulum of the primitive pharynx starting during the third week of life. Its structure is highly organized, being able to synthesize, store and secrete the thyroid hormones. The morphological and functional unit of the gland is the follicle, a structure with a spherical pattern consisting of a single layer of epithelial cells - the follicular cells - surrounding a central lumen filled with colloid. The colloid is of viscous consistency and predominantly consists of thyroglobulin, a protein that anchors in its peptides the precursors of thyroid hormones.

The height of follicular cells, the dimensions of the follicles and the quantity of colloid they contain vary according to the functional activity of the gland and are mainly controlled by the pituitary Thyrotropin hormone (TSH)
The adult thyroid contains about 3 million follicles of a mean size of $300 \mu \mathrm{m}$, which jointly form the parenchyma of the gland and the connective tissue present in the stroma, which separates the lobules (20 to 40 follicles).

Goiter is the increased volume of the thyroid and may be diffuse or nodular and may be due to continuous or repeated hyperplasia. Thyroid nodules are very frequent in the general population and are benign in more than $90 \%$ of cases, although the possibility of malignancy should be considered in all patients involved. Regressive changes may be present in the thyroid, such as infarctions, fibrosis, calcifications, and formation of cysts with a surrounding fibrous capsule. True simple thyroid cysts originating from benign epithelial cells are rare. In a 1995 ultrasound study of patients with 3483 nodules larger than $10 \mathrm{~mm}$, only seven fully cystic nodules were detected.

Most cystic nodules are partially solid structures with cystic degeneration (mixed or complex nodules). Complex nodules are common. In a review of 1128 patients with 1458 thyroid nodules evaluated by ultrasound-guided fine needle aspiration biopsy (FNAB), 53.5\% were partially cystic, with the cystic portion being more than $75 \%$ in $13.7 \%$ of cases. ${ }^{2}$ Thyroid cysts are usually benign, 
but may occasionally contain a malignant solid component. They are usually asymptomatic and may develop symptoms or be discovered in routine physical examinations or during radiological neck procedures, when they are called thyroid incidentalomas. ${ }^{3}$ The clinical-laboratory characteristics of solid or complex thyroid nodules are well known due to their possible association with malignancy, but the characteristics of simple cystic nodules are not. ${ }^{4}$

\section{Objective}

To assess the laboratory and ultra -sonographic characteristics of patients with simple thyroid cysts and to compare them to those of patients with pure solid nodules and those of patients with complex or mixed nodules (solid with cystic degeneration).

\section{Material and methods}

We studied 225 patients with thyroid nodules (18 men and 207

Table I Mean Indicators in each group women) ranging in age from 18 to 87 years. The patients were divided into 4 groups:

GROUP 1: 20 patients with A SINGLE SIMPLE CYST (2 men and 18 women).

GROUP2: 40 patients with SIMPLE CYSTS and PURE SOLID NODULES ( 1 man and 39 women).

GROUP 3: 70 patients with a NODULE/PURE SOLID NODULES ( 8 men and 62 women).

GROUP 4: 95 patients with MIXED NODULES ( 7 men and 88 women).

The patients were submitted to electro chemiluminescence determination of TSH $(\mathrm{RV}=0.27-4.5 \mu \mathrm{IU} / \mathrm{L})$, of $\mathrm{F}$ T4 $(\mathrm{RV}=0.9$ $1.9 \mathrm{ng} / \mathrm{dl})$, FT3 (RV=2.0-4.4pg/ml), Tg (RV=1.4-78ng/ml), AntiTPO $(\mathrm{RV}=<34 \mathrm{IU} / \mathrm{ml})$, Anti $\mathrm{Tg}(\mathrm{RV}=<115 \mathrm{IU} / \mathrm{ml})$, and $\mathrm{TRAB}$ $(\mathrm{RV}<1.75 \mathrm{IU} / \mathrm{L})$. These results are listed in Table 1.

\begin{tabular}{llllllll}
\hline GROUPS & TSH & T4L & T3L & THYROGL & ANTI-TPO & ANTI-TG & TRAB \\
\hline I & 3.01 & 1.14 & 2.74 & 39.00 & 39.98 & 32.14 & 0.3 \\
2 & 2.29 & 1.18 & 2.81 & 34.77 & 13.98 & 15.45 & 0.3 \\
3 & 1.94 & 1.16 & 2.79 & 45.18 & 42.39 & 43.96 & 0.3 \\
4 & 2.61 & 1.21 & 3.12 & 74.96 & 74.30 & 66.30 & 0.3 \\
\hline
\end{tabular}

$\mathrm{TSH}=\mu \mathrm{lU} / \mathrm{ml} ; \mathrm{FT} 4=\mathrm{ng} / \mathrm{dl} ; \mathrm{FT3}=\mathrm{pg} / \mathrm{dl} ; \mathrm{Tg}=\mathrm{ng} / \mathrm{ml} ; \mathrm{Anti} \mathrm{TPO}=\mathrm{iu} / \mathrm{ml} ; \mathrm{AntiTg}=\mathrm{IU} / \mathrm{ml} ; \mathrm{TRAB}=\mathrm{IU} / \mathrm{L}$

Ultrasound examination was applied to the patients with palpable thyroid modules or nodules detected during routine physical examination and to patients submitted to imaging exams of the anterior cervical region for another diagnosis which had revealed the presence of a thyroid nodule. The ultrasound imaging system 8000 EX (Samsung Medison Co., Seoul, Korea) was used and the lesions detected were classified as SIMPLE CYSTS, PURE SOLID NODULES, and COMPLEX or MIXED NODULES. Ultrasound examination was also used to guide FNA of nodules larger than 10 $\mathrm{mm}$ and the aspirated material was stained with hematoxylin-eosin and submitted to histopathology examination.

\section{Statistical analysis}

Statistical significance was calculated by the Chi-square test, which did not reveal any difference. ${ }^{5}$

\section{Results}

As shown in Figure 1, age ranged from 18 to 70 years (mean: 47.2) in GROUP 1 (Single SIMPLE CYSTS), from 22 to 85 years (mean: 59.1) in GROUP 2 (MULTIPLE SIMPLE CYSTS), from 26 to 85 years (mean: 54.5) in GROUP 3 (PURE SOLID NODULES), and from 15 to 85 years (mean: 53) in GROUP $4 .{ }^{6}$ Statistical analysis of the laboratory variables for the four groups by analysis of variance 5 showed the following $\mathrm{p}$ values: Table 2 .

Table $2 \mathrm{P}$ value resulting from analysis of variance
The value of the anti-TSH receptor antibody was the same for all four groups $(\mathrm{RV}=0.3)$. The age and thyroglobulin variables showed statistically significant differences by the Dunn post-test. ${ }^{5}$ Among the men with simple cysts, one was a hyperthyroid patient and 2 were euthyroid. Among the 57women with simple cysts, 14 were euthyroid, 18 had subclinical hypothyroidism, 10 had clinical hypothyroidism, 11 had subclinical hyperthyroidism, 3 had clinical hyperthyroidism, and 1 had a papillary thyroid carcinoma. The mean values of TSH, FT4, FT3, Tg, Anti-TPO, Anti-Tgand TRAB are listed in Table 2.

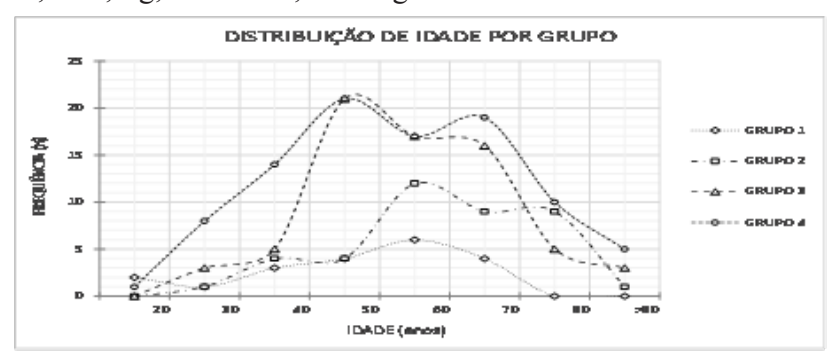

Figure I Age distribution of the four groups of patients with thyroid nodules. AGE DISTRIBUTION PER GROUP.

Group I............

FREQUENCY (n)

AGE (years)

\begin{tabular}{lllllllll}
\hline VARIABLE & AGE & SEX & TSH & T4L & T3L & THYROGL & AntiTPO & AntiTg \\
\hline PVALUE & 0.0270 & 0.4038 & 0.2900 & 0.6375 & 0.2201 & 0.0113 & 0.2113 & 0.1027 \\
\hline
\end{tabular}




\section{Discussion}

Thyroid nodules are defined as an abnormal growth of thyroid cells forming a lump inside the gland and consisting of thyroid cells or other cells with an accumulation of thyroid hormones called colloid. Thyroid nodules are relatively common, occurring in about $6 \%$ of adult women and $2 \%$ of men. An accurate ultrasound evaluation reveals that approximately one third of women and one fifth of men have small nodules in their glands. ${ }^{7}$

Thyroid nodules vary widely in size, many of them being palpable, but most of them are too small to be seen or palpated. Most thyroid nodules are asymptomatic. ${ }^{2}$ Indeed, detection of asymptomatic thyroid nodules as incidental findings on radiological evaluation, that include the neck, had increased. One detected, these thyroid nodules require additional evaluation. ${ }^{7}$

Nodules containing only thyroid tissue are called SOLID NODULES, those containing only fluid are called SIMPLE CYSTS, and nodules that are partially solid and partially fluid are called MIXED or COMPLEX NODULES., ${ }^{2,7}$ Although most thyroid nodules are benign, a small proportion of them contain thyroid carcinoma. ${ }^{8}$ Thus, all thyroid nodules should be evaluated in order to diagnose and treat thyroid cancer in its earliest stage. ${ }^{9-13}$

CYSTS consisting only of fluid have a very low probability of being malignant. ${ }^{9}$ SIMPLE CYISTS with speculated or micro lobulated margins have a better probability of being associated with malignancy $(58.3 \%-\mathrm{p}=0.003){ }^{8}$ CYSTS with solid projections (vegetation's) into their interior have a greater possibility of being malignant than pure cysts. ${ }^{8,14-18}$ All the cases of simple cysts, in this study, did not present vegetations, all being benign. Large SIMPLE CYSTS and COMPLEX CYSTS should be aspirated in order to rule out the presence of malignancy. ${ }^{10-12}$ The risk of a COMPLEX CYST to be malignant seems to be proportional to the degree of its solid component. When the solid component of a cyst is at least $50 \%$, the risk of malignancy reaches $20 \%$. The risk of malignancy for large cysts with a small solid component is low, about 5\%. ${ }^{14,16,18,19}$

In the present study, all Simple Cysts and Complex Cysts larger than $10 \mathrm{~mm}$ were found to be benign when submitted to cytology, reflecting the idea that cysto represent progressive/degenerative progression of the thyroid. The patient with a Papillary Carcinoma had a fully solid nodule. ${ }^{20}$

There was no association between the presence of SINGLE or MULTIPLE SIMPLE CYSTS and the concomitant presence of thyroid disease, indicating that these alterations are a consequence of processes located within the thyroid. Anti TPO, Anti Tg and Tg levels were higher among patients with SIMPLE CYSTS and COMPLEX NODULES, leading us to speculate about the involvement of the immune system in these processes. However, this is a small study to establish such a conclusion, deserving an extension to a better evaluation.

\section{Conclusion}

SIMPLE CYSTS were not infrequent in the present population. SINGLE SIMPLE CYSTS occurred in a younger population than the remaining types of nodules and were less frequent than SIMPLE CYSTS associated with SOLID NODULES. SIMPLE CYSTS and those associated with SOLID NODULES and COMPLEX CYSTS were all benign in the present study. COMPLEX CYSTS were the most frequent among these patients and were also the largest. Anti TPO, Anti Thyroglobulinand Thyroglobulin levels were higher in the presence of CYSTS or SOLID NODULES and Clinical Hypothyroidism or Hashimoto Thyroiditis concomitant. The only carcinoma case occurred in a patient with a single solid thyroid nodule.

\section{Acknowledgements}

None.

\section{Conflict of interest}

The author declares no conflict of interest.

\section{References}

1. Frates MC, Benson CB, Doubilet PM, et al. Prevalence and distribution of carcinomas in patients with solitary and multiple thyroid nodules on sonography. J Clin Endocrinol Metab. 2006;91(9):3411-3417.

2. Alexander EK, Heering JP, Benson CB, et al. Assessment of non -diagnostic ultrasound-guided fine needle aspiration of thyroid nodules. J Clin Endocrinol Metab. 2002;87(11):4924-4927.

3. Nicole Massoli, Nizam Soubhi M, Massaferri Ernest L. Cystic thyroid nodules diagnostic and therapeutic dilemmas. The Endocrinologist. 2002;12(3):185-198

4. Tan GH, Gharib H. Thyroid incidentalomas: management approaches to nonpalpable nodules discovered incidentally on thyroid imaging. Ann Intern Med. 1997;126(3):226-231.

5. Montgomery Douglas C, Runger George C. Applied statistics and probability for engineers. John Wiley, Sons 3rd edition; 2003.

6. Graph Pad Prism version 6.01 for windows, Graph ped software, USA: La Jolla California.

7. Cappola AR, Mandel SJ. Improving the long-term management of benign thyroid nodules. JAMA. 2015;313(9):903-904.

8. Nicole Massoli, Nizam Soubhi M, Massaferri Ernest L. Cystic thyroid nodules. Diagnostic and therapeutic dilemmas. The Endocrinologist. 2002;12(3):185-198

9. Hoang JK, Langer JE, Middleton WD, et al. Managing incidental thyroid nodules detection imaging: ACR Incidental Thyroid Findings Committee. J Am Coll Radiol. 2015;12(2):143-150.

10. Gharib H, Hegedüs L, Pacella CM, et al. Clinical review: Nonsurgical, image-guided, minimally invasive therapy for thyroid nodules. $J$ Clin Endocrinol Metab. 2013;98(10):3949-3957.

11. Nami Azar, Craig Lance, Dean Nakamoto, et al. Ultrasonography thyroid findings suspicious for malignancy. Diagnostic Cytopathol. 2013;41(12):1107-1114.

12. Durante $\mathrm{C}$, Costante $\mathrm{G}$, Lucisano $\mathrm{G}$, et al. The natural history of benign thyroid nodules. JAMA. 2015;13(9):926-935.

13. Gharib H, Papini E, Paschkc R. et al. Task AACE/ AME/ ETA, task force on thyroid nodules. American association of clinical endocrinologists, Associazone medici endocrinologi and european thyroid association medical guidelines for clinical pratice for the diagnosis and management of thyroid nodules. $J$ Endocrinol Invest. 2015;33:1-50.

14. Haugen BR, Alexander EK, Bible KC, et al. American thyroid association management guidelines for adults patients with thyroid nodules and differentiated thyroid cancer. Thyroid. 2016;26(1):1-133.

15. Lee MJ, Kim EK, Kwak JY, et al. Partially cystic thyroid nodules on ultrasound: probability of malignancy and sonographic differentiation. Thyroid. 2009;19(4):341-346. 
16. Park JM, Choi Y, Kwag HJ. partially cystic thyroid nodules: ultrasound findings of malignancy. Korean J Radiol. 2012;13(5):530-535.

17. de los Santos ET, Keyhani-Rofacha S, Cunningham JJ, et al. Cystic thyroid nodules. The dilemma of malignant lesions. Arch Intern Med. 1990;150(7):1422-1427.

18. Bhatia KS, Rasalkar DP, Lee YP, et al. Cystic change in thyroid nodules: a confounding factor for real-time qualitative thyroid ultrasound elastography. Clin Radiol. 2011;66(9):799-807.
19. Porterfield JR, Grant CS, Dean DS, et al. Reliability of benign fine needle aspiration cytology of large thyroid nodules. Surgery. 208;144(6):963968

20. Brito JP, Gionfriddo MR, Al Nofal A, et al. The accuracy of thyroid nodule ultrasound to predict thyroid cancer: systematic review and metaanalyses. J Clin Endocrinol Metab. 2014;99(4):1253-1263. 